\title{
A PROPER SELECTION OF HOT AND COLD UTILITIES IN A PLANT CONTAINING MULTIPLE HEAT EXCHANGER NETWORKS
}

\author{
F. Pourfayaz ${ }^{1}$, A. Kasaeian ${ }^{1, *}$, M. Mehdizadeh Fard ${ }^{1}$
}

\begin{abstract}
In this paper, the hot and cold utilities of a complex natural gas refinery containing multiple heat exchanger networks (HENs) were properly selected. Following using pinch analysis for designing the HENs of the natural gas refinery, this selection could be done by considering available utilities in the plant under consideration. The plant network was divided into the five heat exchanger networks for better and precise estimation of utility requirements in each smaller network. By comparing the type and temperature level of the utility required in each network, the best utility could be selected, in order to use as the heating and cooling media in the plant network with a considerable reduced operating cost of the system. The results show that in the new network design, there was about 38 and $100 \%$ reduction in cooling air and BFW respectively, but $45 \%$ increase in cooling water, as cold utilities and almost 64.4 , 30.0, 90.9 and $100 \%$ reduction in HP steam, LP steam, hot flue gas and electric heater as hot utilities, respectively relative to the existing network.
\end{abstract}

Keywords: Practical Pinch Analysis, Heat Exchanger Network, Hot and Cold Utilities, Appropriate Placement Principle

\section{INTRODUCTION}

Because of increasing energy costs in recent years, the energy saving methods are usually considered at the early stage of any process design, especially in high energy demand industries such as complex oil and gas refineries. The other important reason for the efficient design of any energy system is mainly due to the environmental regulations, forcing to reduce the amount of pollution gases to the atmosphere [1-3]. Especially by the more efficient design of the utility system in a huge chemical processing plant, the amount of energy used in the plant life cycle as heating and cooling media will be reduced significantly. In this regard, a variety of optimization methods considering analytical or experimental techniques are available in the literature, showing how it would be possible to design more and more efficient energy systems for various industries [4-7].

As one of the conceptual methods in process integration, the pinch analysis is widely used as a suitable technique to evaluate and improve the energy systems. The term "Pinch Technology" was introduced by Linnhoff in 1979 to represent a new set of thermodynamically based methods that guarantee minimum energy levels in the design of heat exchanger networks. It is a systematic methodology to achieve utility savings by better process heat integration, maximizing heat recovery and reducing the external utility loads as heating or cooling media in the system. [8] This means in any process integration technique considered for total energy analysis of the systems, the targets for energy saving must be usually set before the design of the heat exchanger network running in the processing plant [9]. In the previous work done by the same authors, it was presented an energy analysis of a complex natural gas refinery by the super-targeting method, showing a considerable saving in yearly energy consumption of the plant [10]. There are a lot of works done in literature and research papers about energy saving techniques using pinch analysis methods, some of them were shown in [10] to [16].

The proper design of the utility system in any processing industry plays an important role in the operational cost of the system, by increasing or decreasing the heating and cooling requirements of the processing units running in the plant. The most usual types of heating media as hot utilities may include HP or LP steam, hot flue gases from furnaces or fired heaters, hot oil or water, electrical heating and some other less common media. Likewise, cold 
utilities, which remove heat from the processes by cooling media, may include cooling water or air, chilled water, refrigeration fluids and so on. Usually, the costs of cooling and heating system together with its operational cost are two most important factors for selection of the best utility media in the system. Especially in a huge natural gas refinery as a high energy demand industry, the efficient design of the utility system will considerably affect the energy saving and operational cost of the plant. It is obvious that it provides the key to choosing the correct levels and loads for the various hot and cold utilities. As a case study, the result of pinch analysis in a complex gas refinery which provided by the same authors in [10], was used to analyse the heat exchanger network running in the plant and consider opportunities to select the best heating and cooling media as the utility requirement of the system, using Appropriate Placement principle.

\section{METHODOLOGY}

The method is based on the concept of integration processes and the basic tools which used in the analysis are: Hot and Cold Composite Curves (HCC/CCC), and Grand Composite Curve (GCC). Pinch technology combines heat and mass balance information into simple charts and graphs to show the potential of energy recovery of the heat exchanger network (HEN).

In this analysis, the following steps were considered:

- Extraction of stream data from different processing units, considering the heat and mass balances of all process streams in the network, in order to calculate total heat exchanged required by the cold and hot streams, provided by hot and cold utilities, respectively.

- Drawing the hot and cold composite curves (HCC \& CCC) as well as grand composite curve (GCC) for all the hot and cold streams in a T-H diagram, to analyze the minimum utility quantities required to solve the heat recovery problem.

- Determine the type and temperature level of utility required as the amount of energy consumption, such as fuel, water, LP and HP steam, refrigerants, air and so on in the network.

- Applying the steps 1 through 3 for all HENs running in the plant under consideration. In the case study of this manuscript, the entire system divided into the five smaller networks (see Table 3 for detail description), each consists of some processing units, so the procedure of utility selection could be applied for all subnetworks in the plant.

- By superposing all the utilities calculated in the previous step for all HENs, the total amount of energy consumption in the utility system of the plant can be determined, and the type and amount of heating and cooling media will be finalized.

\section{CHOICE OF MULTIPLE UTILITY LEVELS BY THE APPROPRIATE PLACEMENT PRINCIPLE}

The Appropriate Placement principle, originally introduced by Townsend and Linhoff in 1983 [8]. It is obvious that it provides the key to choosing the correct levels and loads for the various hot and cold utilities. Normally, because of cost differentials between utilities, it needs naturally to maximize the use of the least expensive ones. This usually led to maximize the use of the coldest hot utility and the hottest cold utility. The shape of the grand composite often dictates the most appropriate choice of levels and loads. Usually, the trade-offs from using multiple utilities are as follows:

- Steam can often be raised more efficiently at a lower temperature level, as more heat can be recovered from boiler flue gases;

- Power can be generated if the steam is let down from a higher pressure through a turbine;

- Lower-temperature steam is at lower pressure and hence the capital cost of the system is less;

- The driving forces between utilities and process are reduced, so that the surface area and capital cost of heaters/coolers will increase;

- Each extra level increases the complexity of design and incurs an additional capital cost for boilers and pipework.

Hence, according to the above consideration, the designer needs to balance the reduction in running cost against the increased capital cost brought about by increasing the number of levels. Based on the types of utility 
available in the plant, the external heating and cooling requirements are supplied as a hot and cold utility, at a specified temperatures sufficient to fulfill the duty. Referring to [17], in this case study, the heating media are high and low-pressure steam from steam boilers and hot flue gases from furnaces. The saturated HP steam at 45 bar and $274^{\circ} \mathrm{C}$ is generated in six gas-fired boilers, followed by letdown stations, in order to produce LP steam at 6.5 bar and $185^{\circ} \mathrm{C}$ by letting saturated high-pressure steam down to the low-pressure level followed by de-superheating. The hot flue gas delivered by gas-fired heaters, as the heating media with the temperature around $250-400{ }^{\circ} \mathrm{C}$. Cooling media are air, chilled and cooling water and low-temperature propane and ethane as refrigerants. The cooling water is recirculated to a cooling system and returned to the cycle, which works in the range $20-40^{\circ} \mathrm{C}$. Air as a cooling medium with the design outdoor temperature of $45^{\circ} \mathrm{C}$, is derived by electrical fans in air cooled heat exchangers. The refrigeration system uses propane and ethane between $-4.0^{\circ} \mathrm{C}$ to $-90^{\circ} \mathrm{C}$.

\section{THE CASE STUDY: A BRIEF DESCRIPTION OF THE PLANT}

The details of a general gas processing plant were shown in [18]. As the case study of this manuscript, a natural gas refinery designed for refining 2 billion standard cubic feet of natural gas feed per day, delivers 50 million cubic meters per day refined gas injecting to national grid pipeline, 2 million cubic meters per day Ethane, 135 tonnes per day NGL products (propane and butane liquids), 80,000 barrels per day gas condensate and 400 tons per day sulfur solids. The main processing units of the natural gas refinery have been indicated in Table 1 . Detail information about this refinery was shown in [10], [17] and [19-22].

Table 1. Main process units of a complex natural gas refinery

\begin{tabular}{|c|c|c|}
\hline UNIT Name & UNIT No. & DESCRIPTION \\
\hline $\begin{array}{l}\text { The gas receiving } \\
\text { facilities }\end{array}$ & Unit 100 & Reception Facilities \\
\hline \multirow{14}{*}{$\begin{array}{l}\text { Gas Refining and } \\
\text { Liquid Processing }\end{array}$} & Unit 101 & Gas Treating \\
\hline & Unit 104 & Dehydration and Mercury Guard \\
\hline & Unit 105 & Ethane Recovery \\
\hline & Unit 106 & Export Gas Compression and Metering \\
\hline & Unit 107 & NGL Fractionation \\
\hline & Unit 109 & Sour Water Stripping \\
\hline & Unit 111 & Propane Refrigeration Unit \\
\hline & Unit 113 & $\begin{array}{c}\text { Caustic Regeneration Unit for } \mathrm{C} 3 \text { and } \mathrm{C} 4 \\
\text { SULFREX }\end{array}$ \\
\hline & Unit 114 & Propane Treatment and Drying \\
\hline & Unit 115 & Butane Treatment and Drying \\
\hline & Unit 116 & Ethane Treatment and Drying \\
\hline & Unit 146 & Chemicals Storage \\
\hline & Unit 147 & Propane Storage \\
\hline & Unit 148 & Butane Storage \\
\hline \multirow{3}{*}{ Condensate stabilization } & Unit 103 & Condensate Stabilization \\
\hline & Unit 110 & Back-up Stabilization \\
\hline & Unit 112 & Demercaptinize Condensate (DMC) \\
\hline $\begin{array}{l}\text { Sulfur recovery and } \\
\text { storage }\end{array}$ & Unit 108 & Sulfur Recovery \\
\hline $\begin{array}{l}\text { MEG regeneration and } \\
\text { re-injection }\end{array}$ & Unit 102 & MEG regeneration \\
\hline Utility services & Unit $120-132$ & $\begin{array}{c}\text { The utility equipment and accessories (HP/LP } \\
\text { Steam, Cooling air and water, Refrigerants and } \\
\text { Power generation) }\end{array}$ \\
\hline
\end{tabular}


By extraction of all the process and utility data from engineering documents of the plant, the total energy requirements due to the utility consumptions of the plant were determined and summarized in Table 2. According to the Table 2, the cold and hot utilities of the existing plant were about 213.7 MW and 171.4 MW respectively. Meanwhile, there was 163.5 MW as the available heat recovery in the plant network [10]. According to the results, there was a huge energy consumption to operate the plant, with about $385 \mathrm{MW}$ for the heating and cooling requirements of the process units. Therefore, any improvement in energy saving of the HEN running in the plant, will significantly reduce the annual operational cost, accordingly.

Table 2. Hot and cold utility consumptions in the existing plant

\begin{tabular}{|c|c|c|c|}
\hline Service & Type of Utility & $\begin{array}{c}\text { Consumption } \\
\text { (KW) }\end{array}$ & $\begin{array}{c}\text { Total } \\
\text { (KW) }\end{array}$ \\
\hline \multirow{2}{*}{ Cold Utility y } & Cooling Air & 167,653 & \multirow{2}{*}{213,721} \\
\cline { 2 - 3 } & Cooling Water & 46,068 & \\
\hline \multirow{2}{*}{ Hot Utility } & HP/LP Steam & 160,398 & \multirow{2}{*}{171,422} \\
\cline { 2 - 3 } & Fuel Gas & 11,024 & \\
\hline \multicolumn{3}{|c|}{ Total Utility Consumption } & 385,143 \\
\hline \multicolumn{3}{|c|}{ Heat Recovery } & 163,527 \\
\hline
\end{tabular}

\section{RESULTS AND DISCUSSION}

In this plant, the total numbers of hot and cold flow streams were 66 and 44 respectively and the total heat load released by all hot streams is $377,248 \mathrm{KW}$, whereas total heat load gained by all cold streams is $334,950 \mathrm{KW}$. The graph of hot and cold composite curves can be developed by drawing all stream temperatures versus cumulative heat loads of hot and cold streams at each temperature level, respectively (Fig. 1).

Referring to the Fig.1, the pinch temperature difference $\Delta \mathrm{T}_{\min }$ in the chart was determined around $66{ }^{\circ} \mathrm{C}$, with the pinch at $97.8^{\circ} \mathrm{C}$ shifted temperature, corresponding to $130.8^{\circ} \mathrm{C}$ for $\mathrm{HCC}$ and $64.8^{\circ} \mathrm{C}$ for $\mathrm{CCC}$. The Figure shows that total heat recovered by the network is about $163.5 \mathrm{MW}$, with energy targets of $171.4 \mathrm{MW}$ hot utility and 213.7 MW cold utility.

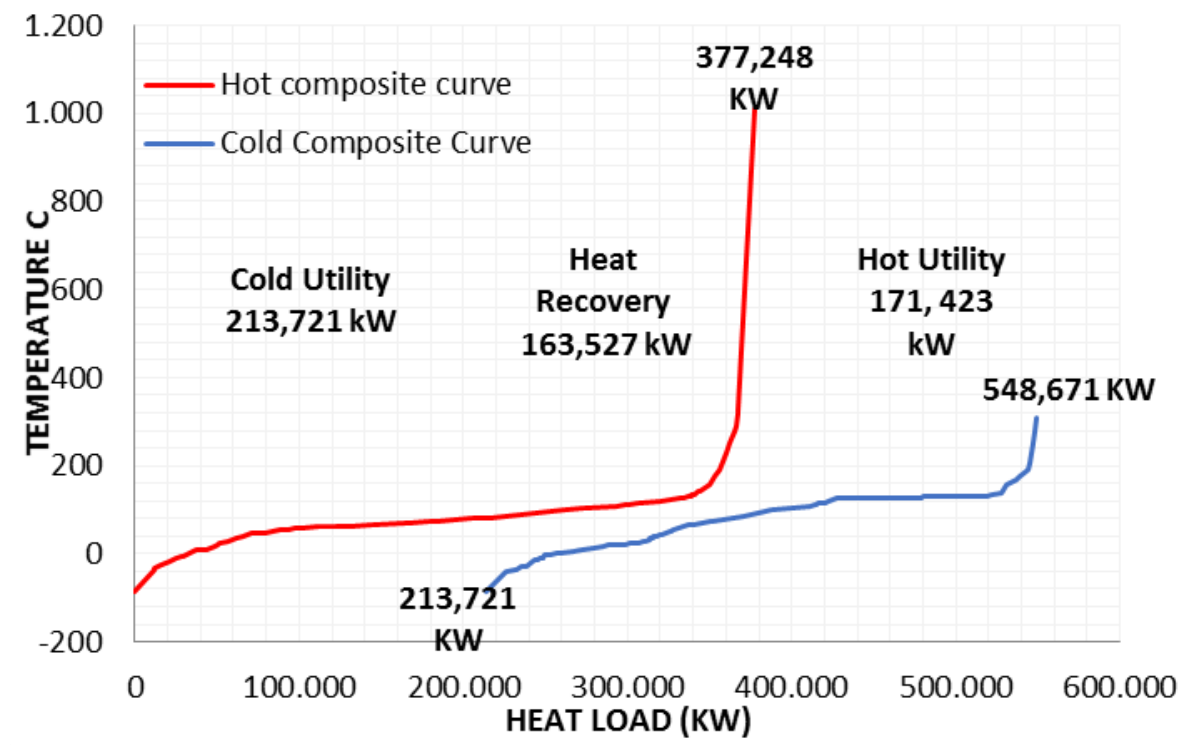

Figure 1. Hot and cold composite curves $(\mathrm{HCC} / \mathrm{CCC})$ of the plant network

The plant was divided into the five main areas, each consisting of some neighbor processing units. The nomination of the five areas and the contribution of the process units are shown in Table 3. Therefore, there is a Heat 
Exchanger Network in each area, consisting of all the heat exchangers located in that area. For more detail information about the plant description and process data, refer to Mehdizadeh Fard et al. [10].

Table 3. Five divided areas in the plant and the relevant assigned units

\begin{tabular}{|c|c|}
\hline Zone Number & Unit Number \\
\hline AREA 1 & Units $100 / 103 / 109 / 110$ \\
\hline AREA 2 & Units $101 / 104 / 105 / 106 / 111$ \\
\hline AREA 3 & Units $107 / 113 / 114 / 115 / 116$ \\
\hline AREA 4 & Unit 108 \\
\hline AREA 5 & Units $146 / 147 / 148$ \\
\hline
\end{tabular}

The total numbers of heat exchangers in the network are equal to 104 units with total 208 fluid streams, consisting of 66 hot process streams, 44 cold process streams and 98 utility streams such as HP and LP steams, hot flue gases, cooling water and air. For the details of the hot and cold flow streams, inlet and outlet temperatures, and the heat loads refer to Mehdizadeh Fard et al. [10].

\section{AREA No. 1 (Units 100/103/109/110):}

By drawing hot and cold composite curves and considering the hot and cold utility requirements from heat balance of the streams in this network, the hot and cold composite curves and grand composite curve were shown in the Figures 2 and 3, respectively. The Figures show that this case was a special type of the pinch analysis, known as threshold problem. In this area, total numbers of hot and cold flow streams were 10 and 13 respectively. The total heat recovered by the network was about $58,707 \mathrm{KW}$, with energy targets of $33,458 \mathrm{KW}$ hot utility and no cold utility (Fig. 2).

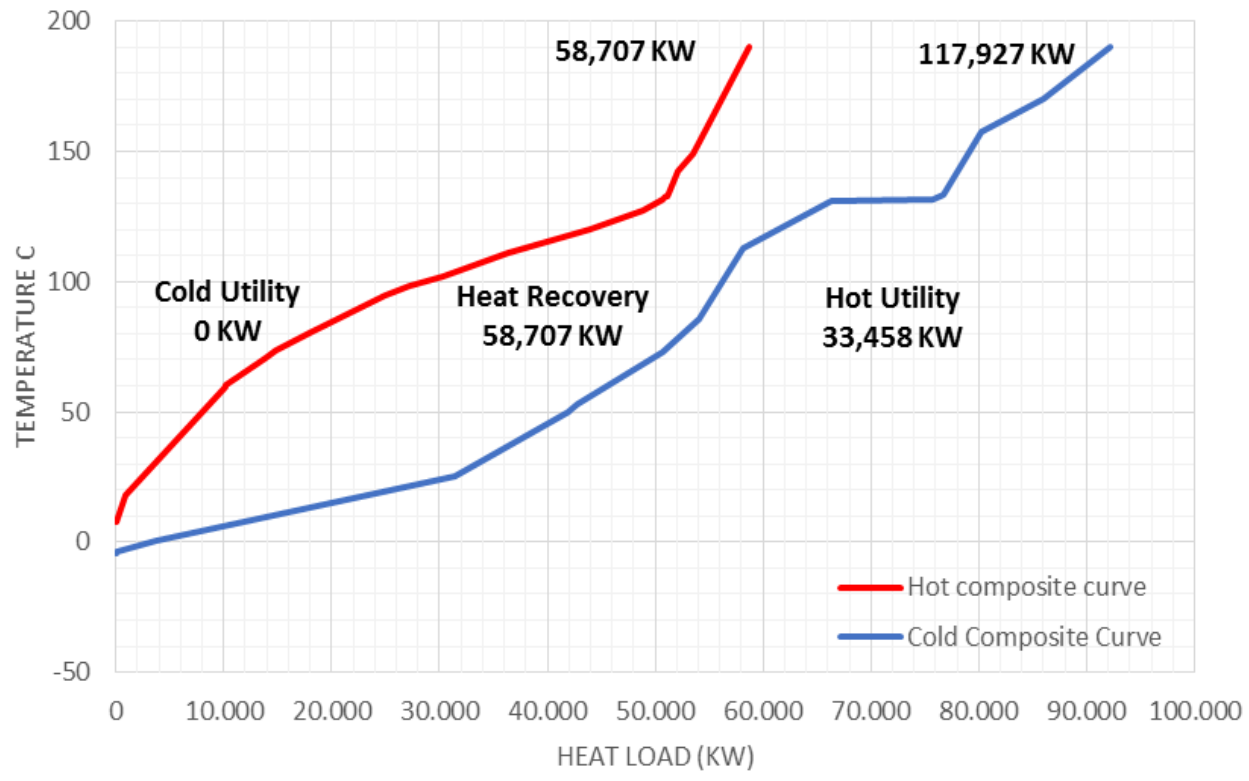

Figure 2. Hot and cold composite curves in Area 1

Referring to the GCC of the network as shown in the Figure 3, the selection of best utility could be done by the Appropriate Placement principle [8]. The type and temperature level of the appropriate utilities were shown in the Figure 3. It is clear that there are two temperature levels for HP steam as heating media, at $210 \mathrm{C}$ and $160 \mathrm{C}$, and no cold utility. 


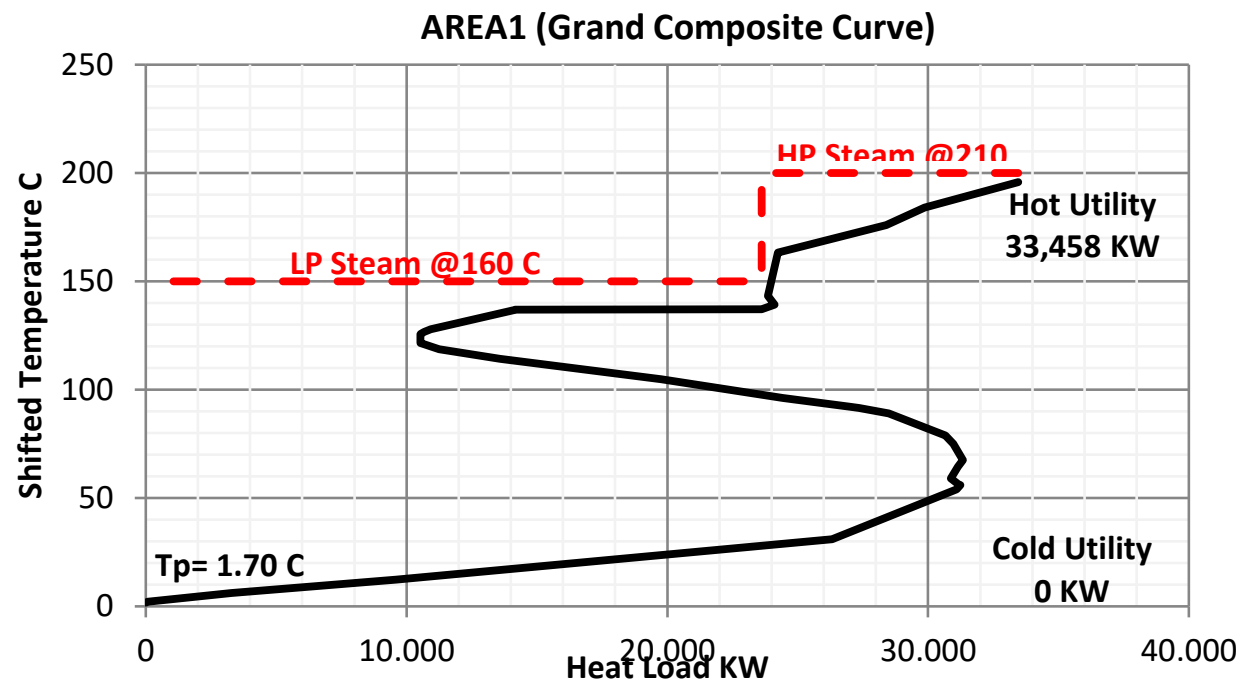

Figure 3. Grand composite curve in Area 1

\section{AREA No. 2 (Units 101/104/105/106/111):}

By drawing hot and cold composite curves and considering the hot and cold utility requirements from heat balance of the streams in this network, the hot and cold composite curves and grand composite curve were shown in the Figures 4 and 5, respectively. In this area, total numbers of hot and cold flow streams were 13 and 15 respectively. Hot and cold utility requirements of the existing network in this area were about 19,818 KW and 36,300 $\mathrm{KW}$, respectively, with total heat recovered by the network about 99,620 KW (Figure 4)

Referring to the GCC of the network as shown in the Fig. 5, the selection of best utilities could be done by the same procedure explained for Areal at previous steps. The type and temperature level of the appropriate hot and cold utilities were shown in the same figure. It is clear that there are two temperature levels for the hot utility, i.e. hot flue gas, and HP steam as heating media, and also two temperature levels for the cold utility, i.e. cooling air at $45 \mathrm{C}$ and cooling water at $35 \mathrm{C}$ as cooling media.

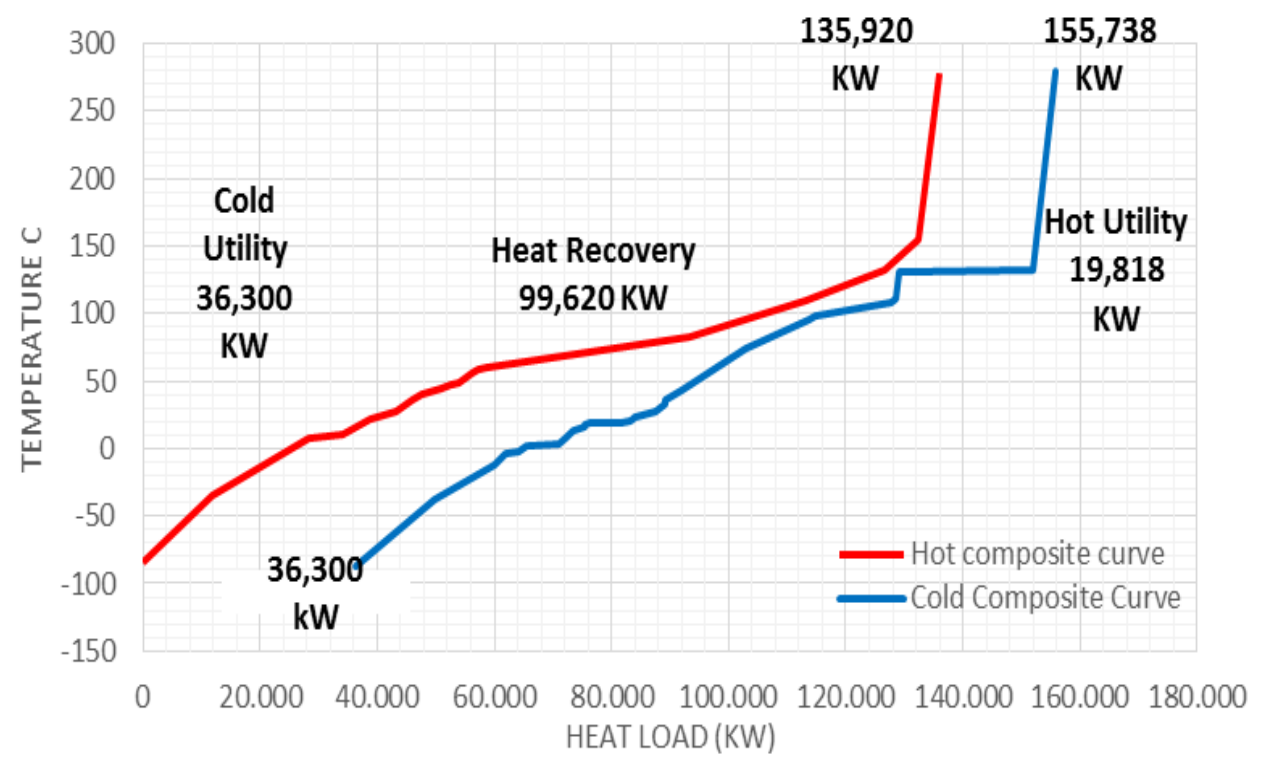

Figure 4. Hot and Cold composite curves in Area 2 


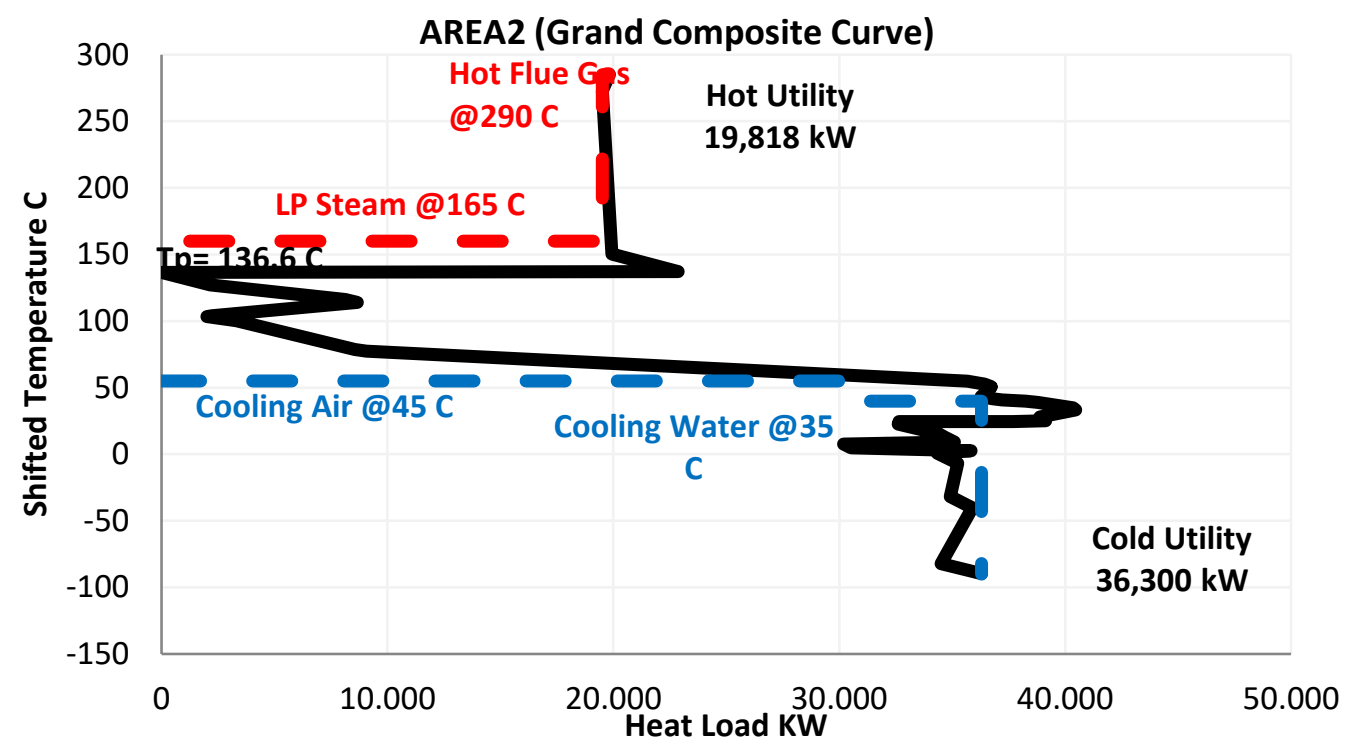

Figure 5. Grand composite curve in Area 2

\section{AREA No. 3 (Units 107/113/114/115/116):}

By drawing hot and cold composite curves and considering the hot and cold utility requirements from heat balance of the streams in this network, the hot and cold composite curves and grand composite curve were shown in the Figures 6 and 7, respectively. In this area, total numbers of hot and cold flow streams were 18 and 9 respectively. Hot and cold utility requirements of the existing network in this area were about 26,072 KW and 31,850 KW, respectively, with total heat recovered by the network about 11,837KW (Fig. 6).

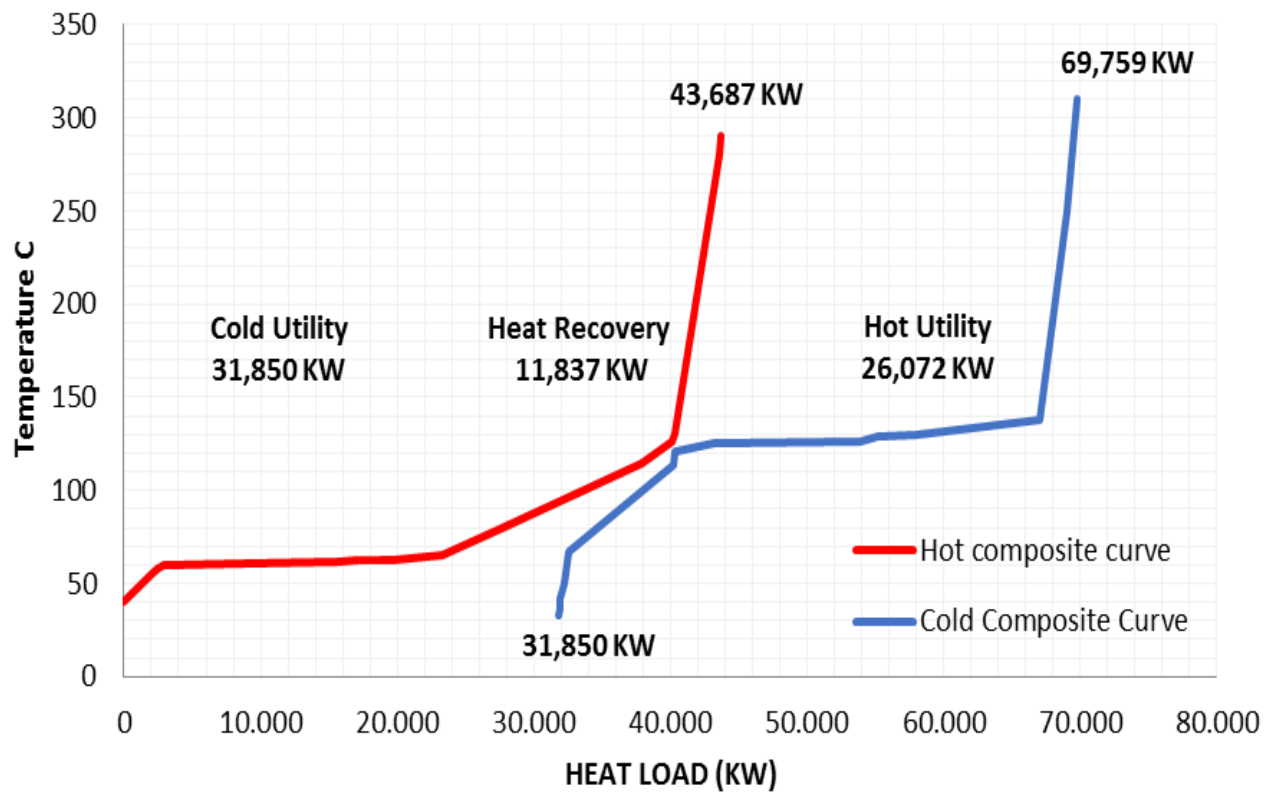

Figure 6. Hot and Cold composite curves in Area 3

Referring to the GCC of the network as shown in the Fig. 7, the selection of best utilities could be done by the same procedure explained for previous networks. The type and temperature level of the appropriate hot and cold 
utilities were shown in the same figure. It is clear that there are two temperature levels for the hot utility, i.e. hot flue gas at 320 and HP steam at $160 \mathrm{C}$ as heating media, and two temperature levels for the cold utility, i.e. cooling air at $45 \mathrm{C}$ and cooling water at $30 \mathrm{C}$ as cooling media.

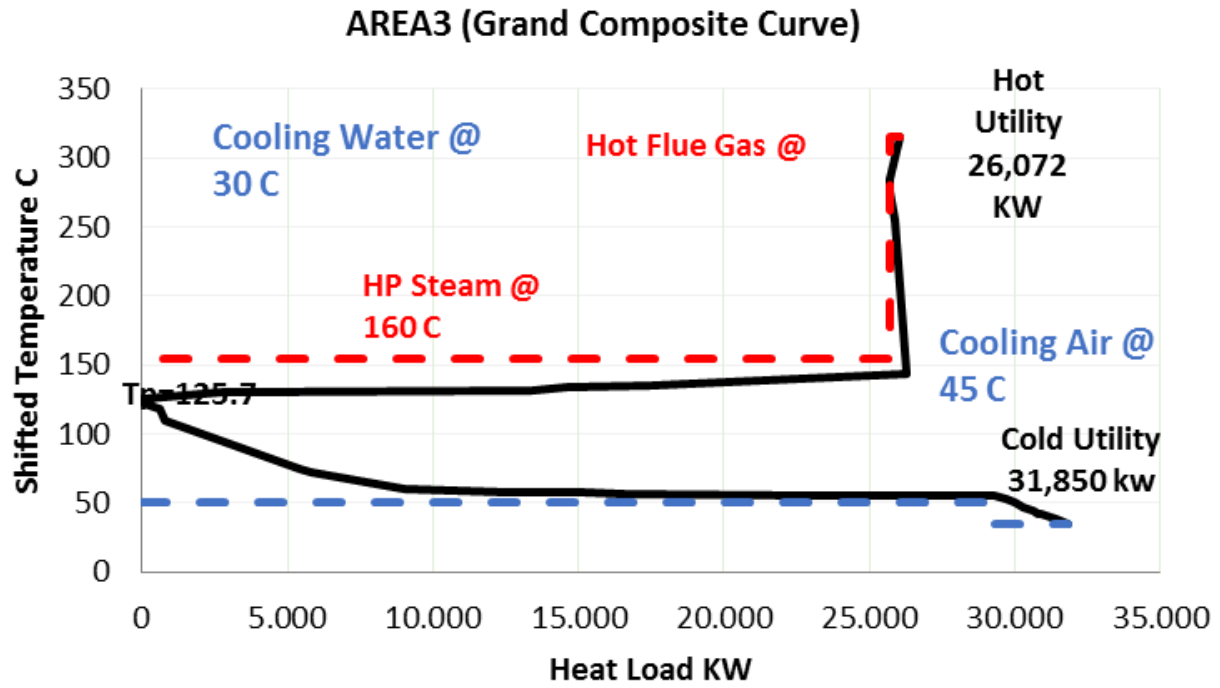

Figure 7. Grand composite curve in Area 3

\section{AREA No. 4 (Unit 108)}

By drawing hot and cold composite curves and considering the hot and cold utility requirements from heat balance of the streams in this network, the hot and cold composite curves and grand composite curve were shown in the Figures 8 and 9, respectively. In this area, total numbers of hot and cold flow streams were 12 and 3 respectively. Hot and cold utility requirements of the existing network in this area are about 23,675 KW and 54,348 KW, respectively, with total heat recovered by the network about 49,843 KW (Fig. 8).

Referring to the GCC of the network as shown in the Fig. 9, the selection of best utilities could be done by the same procedure explained in previous steps. The type and temperature level of the appropriate hot and cold utilities were shown in the same figure. It is clear that there is only one temperature level required as the hot utility, i.e. LP steam at $160 \mathrm{C}$ as heating media, but two temperature level as the cold utility, i.e. cooling air and cooling water at $45 \mathrm{C}$ and $30 \mathrm{C}$ respectively, as cooling media.

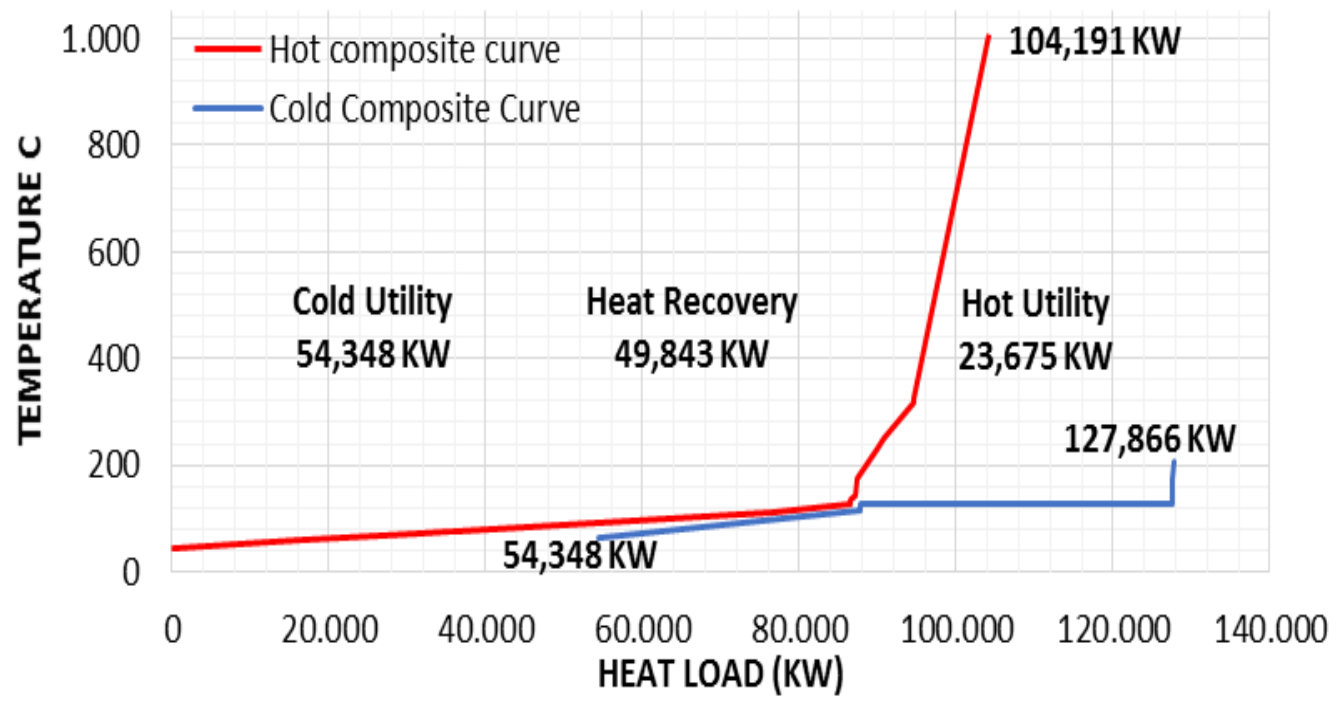

Figure 8. Hot and Cold composite curves in Area 4 


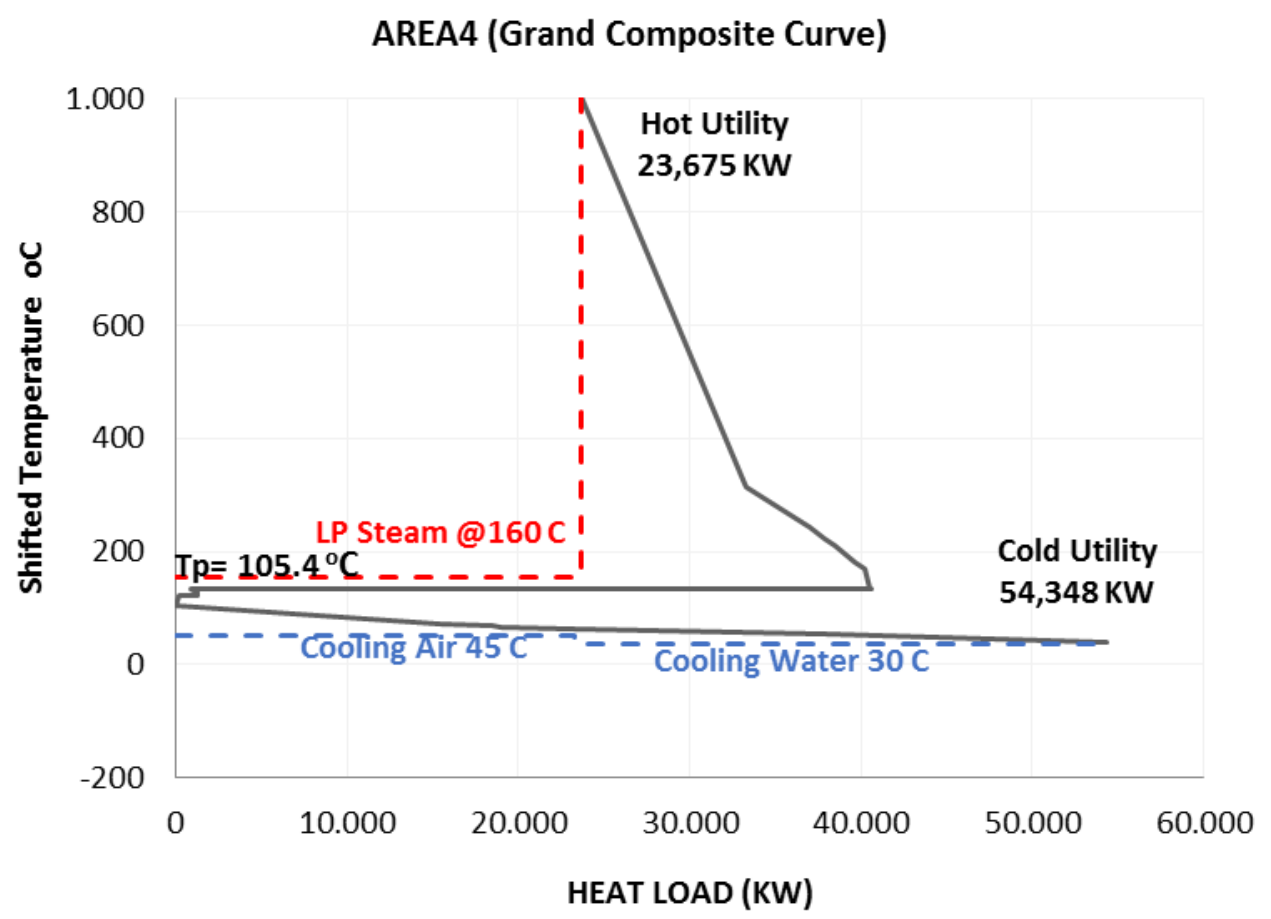

Figure 9. Grand composite curve in Area 4

\section{AREA No. 5 (Units 146/147/148):}

By drawing hot and cold composite curves and considering the hot and cold utility requirements from heat balance of the streams in this network, the hot and cold composite curves and grand composite curve are shown in the Figs. 10 and 11, respectively.

In this area, total numbers of hot and cold flow streams are 10 and 7 respectively. Cold utility requirement of the existing network in this area is about $22,823 \mathrm{KW}$, and no need to heating media as the hot utility. The graph shows that the heat recovery is equal to $11,920 \mathrm{KW}$, which is exactly equal to the heat gained by the cold composite curve. Therefore, in this special case, the heat recovery is limited by the total heat received by the cold composite curve (Fig. 10).

Referring to the GCC of the network as shown in the Fig. 11, the selection of best utilities could be done by the same procedure explained in previous steps. The type and temperature level of the appropriate hot and cold utilities were shown in the same figure. It is clear that there is only one temperature level required as the cold utility, i.e. cooling water at $35 \mathrm{C}$ as cooling media, and no need to the hot utility.

\section{Summary of the results from all five HENs}

By the combination of the results obtained previously in each area of the refinery, the total energy consumption as the hot and cold utilities could be determined for all networks and the results were shown in Table 4 . Meanwhile, the available hot and cold utility of the existing plant networks were summarized in Table 5. The comparison of the results shows that the utility consumption in the new network design would be much better than the existing one, and there is about $35.5 \%$ energy saving by applying the pinch analysis of the system. Also, the results show that there is a considerable saving in both heating and cooling media. There is about $32 \%$ reduction in cooling air and water, and almost $40 \%$ saving in steam consumption, relative to the existing network. In addition, the type and temperature level of the heating and cooling media were more reasonable by economic consideration. 
Journal of Thermal Engineering, Research Article, Vol. 5, No. 4, pp. 341-354, July, 2019

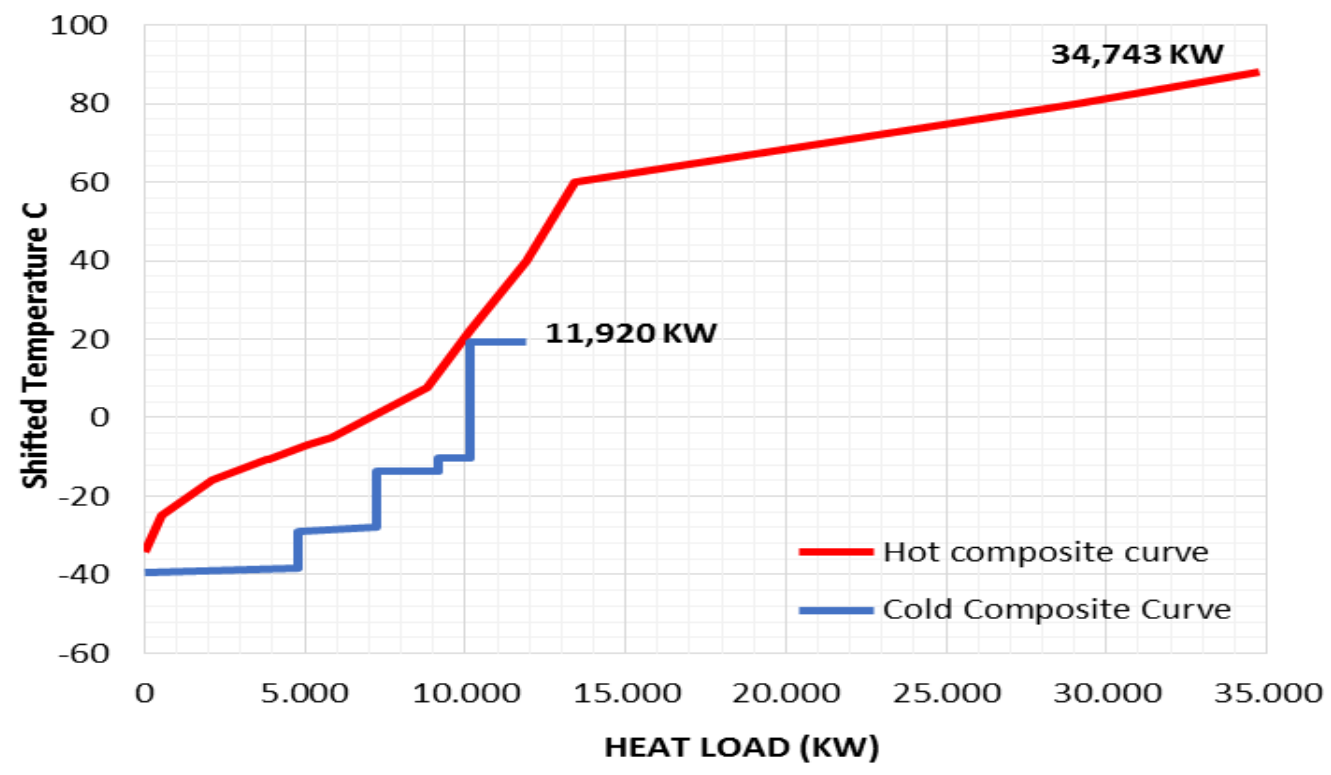

Figure 10. Hot and Cold composite curves in Area 5

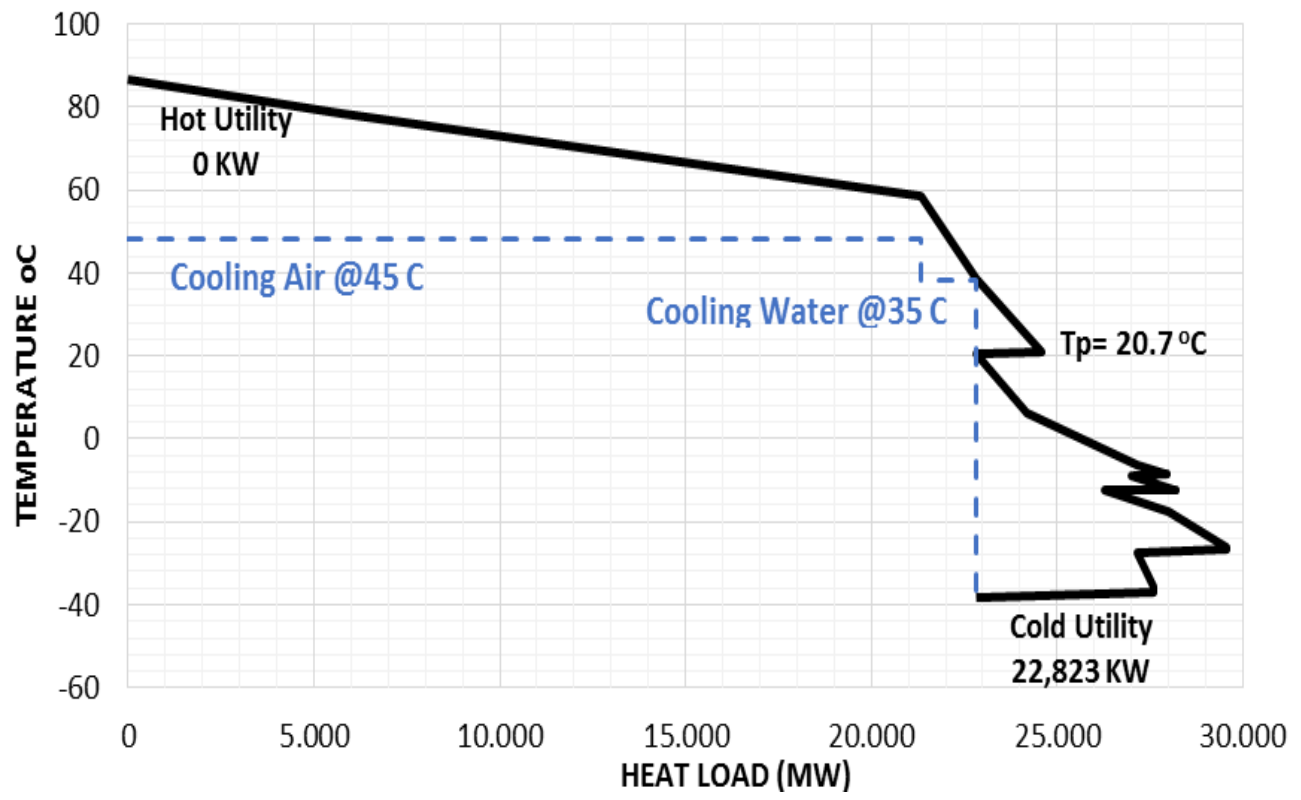

Figure 11. Grand composite curve in Area

The type and temperature level of cooling media were summarized and compared with the existing ones in Table 6. Referring to the table, it was clear that there was about 38 and $100 \%$ saving in the total cooling air and BFW consumption respectively, but $45 \%$ increase of water consumption as cold utilities.

Meanwhile, the type and temperature level of heating media were summarized and compared with the existing ones in Table 7. Referring to the table, it was clear that there was almost 64.4, 30.0, 90.9 and 100\% saving in HP steam, LP steam, hot flue gas and electric heater usage as hot utilities, respectively. 
Journal of Thermal Engineering, Research Article, Vol. 5, No. 4, pp. 341-354, July, 2019

Table 4. Total energy consumption and utility requirement in five networks

\begin{tabular}{|c|c|c|c|c|c|}
\hline \multicolumn{6}{|c|}{ TOTAL ENERGY CONSUMPTION IN FIVE HENS (KW) } \\
\hline \multirow{2}{*}{ Zone No. } & \multicolumn{2}{|r|}{ COLD UTILITY } & \multicolumn{2}{|r|}{ HOT UTILITY } & \multirow{2}{*}{$\begin{array}{c}\text { TOTAL UTILITY } \\
\mathrm{KW}\end{array}$} \\
\hline & KW & Type & KW & Type & \\
\hline Area1 & 0 & - & $\begin{array}{r}9,833 \\
23,625\end{array}$ & $\begin{array}{l}\text { HP Steam @210 C } \\
\text { LP Steam @ } 160 \text { C }\end{array}$ & 33,458 \\
\hline Area2 & $\begin{array}{c}30,190 \\
6,110\end{array}$ & $\begin{array}{c}\text { Cooling Air@45 C } \\
\text { Cooling Water@35 C }\end{array}$ & $\begin{array}{c}308 \\
19,510\end{array}$ & $\begin{array}{c}\text { Hot Flue Gas @290 C } \\
\text { LP Steam @165 C }\end{array}$ & 56,118 \\
\hline Area3 & $\begin{array}{r}29,325 \\
2,525\end{array}$ & $\begin{array}{c}\text { Cooling Air@45 C } \\
\text { Cooling Water@30 C }\end{array}$ & $\begin{array}{c}381 \\
25,691\end{array}$ & $\begin{array}{c}\text { Hot Flue Gas @320 C } \\
\text { LP Steam @160 C }\end{array}$ & 57,922 \\
\hline Area4 & $\begin{array}{l}23,230 \\
31,118\end{array}$ & $\begin{array}{c}\text { Cooling Air@45 C } \\
\text { Cooling Water@30 C }\end{array}$ & 23,675 & LP Steam@160 C & 78,023 \\
\hline Area5 & $\begin{array}{r}21,323 \\
1,500\end{array}$ & $\begin{array}{c}\text { Cooling Air@45 C } \\
\text { Cooling Water@35 C }\end{array}$ & 0 & - & 22,823 \\
\hline All Networks & & 145,321 & & 103,023 & 248,344 \\
\hline
\end{tabular}

Table 5. Total energy consumption and utility requirement in five networks (Existing network)

\begin{tabular}{|c|c|c|c|c|c|}
\hline \multicolumn{6}{|c|}{$\begin{array}{l}\text { TOTAL ENERGY CONSUMPTION IN FIVE HENs (KW) } \\
\text { (Existing Network) }\end{array}$} \\
\hline \multirow{2}{*}{ Zone No. } & \multicolumn{2}{|c|}{ COLD UTILITY } & \multicolumn{2}{|r|}{ HOT UTILITY } & \multirow{2}{*}{$\begin{array}{c}\text { TOTAL UTILITY } \\
\text { KW }\end{array}$} \\
\hline & KW & Type & KW & Type & \\
\hline \multirow{2}{*}{ Areal } & \multirow{2}{*}{23,215} & \multirow{2}{*}{ Cooling Air@45 C } & 27,373 & HP Steam@260C & \multirow{2}{*}{79,888} \\
\hline & & & 29,300 & LP Steam@155C & \\
\hline \multirow{2}{*}{ Area2 } & 53,963 & Cooling Air@45 C & 6,426 & Hot Flue Gas@290 C & \multirow{2}{*}{103,789} \\
\hline & 6,173 & Cooling Water@35 C & 37,227 & LP Steam $155 \mathrm{C}$ & \\
\hline \multirow{3}{*}{ Area3 } & 33,914 & Cooling Air@45 C & 1,125 & Hot Flue Gas $350 \mathrm{C}$ & \multirow{3}{*}{67,954} \\
\hline & \multirow{2}{*}{2,952} & \multirow{2}{*}{ Cooling Water@35 C } & 3,473 & Electric Heater & \\
\hline & & & 26,490 & LP Steam@155 C & \\
\hline \multirow{3}{*}{ Area4 } & 36,738 & Cooling Air@45 C & 246 & HP Steam@255 C & \multirow{3}{*}{110,689} \\
\hline & 16,325 & Cooling Water@30 C & \multirow{2}{*}{39,762} & \multirow{2}{*}{ LP Steam@145 C } & \\
\hline & 17,618 & BFW@120 C & & & \\
\hline \multirow{2}{*}{ Area5 } & 19,823 & Cooling Air@45 C & \multirow{2}{*}{0} & \multirow{2}{*}{ - } & \multirow{2}{*}{22,823} \\
\hline & 3,000 & Cooling Water@30 C & & & \\
\hline All Networks & & 213,721 & & 171,422 & 385,143 \\
\hline
\end{tabular}


Journal of Thermal Engineering, Research Article, Vol. 5, No. 4, pp. 341-354, July, 2019

Table 6. Total cold utility requirement in five networks

\begin{tabular}{|c|c|c|c|}
\hline \multicolumn{4}{|c|}{$\begin{array}{l}\text { Comparison of total cold utilities in exiting network \& network after utilities selection following pinch } \\
\text { analysis }\end{array}$} \\
\hline $\begin{array}{c}\text { Zone } \\
\text { No. }\end{array}$ & Exiting network & $\begin{array}{l}\text { Network after the utilities selection } \\
\text { following pinch analysis }\end{array}$ & $\begin{array}{c}\text { Percent } \\
\text { Change } \\
\text { in Cold } \\
\text { Utility }\end{array}$ \\
\hline Area1 & 23,215 KW Cooling Air@45 C & 0 & $100 \%$ \\
\hline \multirow{2}{*}{ Area2 } & 53,963 KW Cooling Air @ 45 C & 30,190 KW Cooling Air @ 45 C & $44.1 \%$ \\
\hline & 6,173 KW Cooling Water@35 C & 6,110 KW Cooling Water@35 C & $1.0 \%$ \\
\hline \multirow{2}{*}{ Area3 } & 33,914 KW Cooling Air @ 45 C & 29,325 KW Cooling Air@ @ 45 C & $13.5 \%$ \\
\hline & 2,952 KW Cooling Water@35 C & 2,525 KW Cooling Water@30 C & $14.5 \%$ \\
\hline \multirow{3}{*}{ Area4 } & 36,738 KW Cooling Air @ 45 C & 23,230 KW Cooling Air @ 45 C & $36.8 \%$ \\
\hline & 16,325 KW Cooling Water@30 C & 31,118 KW Cooling Water@30 C & $-90.6 \%$ \\
\hline & 17,618 KW BFW@120C & 0 & $100 \%$ \\
\hline \multirow{2}{*}{ Area5 } & 19,823 KW Cooling Air @ 45 C & 21,323 KW Cooling Air@45 C & $-7.6 \%$ \\
\hline & 3,000 KW Cooling Water@30 C & 1,500 KW Cooling Water@35 C & $50 \%$ \\
\hline \multirow{3}{*}{$\begin{array}{c}\text { All } \\
\text { Netwo } \\
\text { rks } \\
\text { (KW) }\end{array}$} & 167,653 KW; Cooling Air @ 45 C & 104,068 KW; Cooling Air @ 45 C & $37.9 \%$ \\
\hline & 28,450 KW; Cooling Water @ 30 \& 35 C & 41,253 KW; Cooling Water @ 30 \& 35 C & $-45.0 \%$ \\
\hline & 17,618 KW; BFW@120C & 0 KW; BFW@120 C & $100 \%$ \\
\hline
\end{tabular}

Table 7. Total hot utility requirement in five networks

\begin{tabular}{|c|c|c|c|}
\hline \multicolumn{4}{|c|}{ Comparison Of hot utilities in exiting network \& network after utilities selection following pinch analysis } \\
\hline Zone No. & Exiting network & $\begin{array}{l}\text { Network after the utilities selection } \\
\text { following pinch analysis }\end{array}$ & $\begin{array}{c}\text { Percent } \\
\text { Reduction in } \\
\text { Hot Utility }\end{array}$ \\
\hline \multirow{2}{*}{ Areal } & 27,373 KW HP Steam@260 C & 9,833 KW HP Steam@210 C & $64.1 \%$ \\
\hline & 29,300 KW LP Steam@155 C & 23,625 KW LP Steam@160 C & $19.4 \%$ \\
\hline \multirow{2}{*}{ Area2 } & 6,426 KW Hot Flue Gas@290 C & 308 KW Hot Flue Gas@290 C & $95.2 \%$ \\
\hline & 37,227 KW LP Steam@155 C & 19,510 KW LP Steam@165 C & $47.6 \%$ \\
\hline \multirow{3}{*}{ Area3 } & 1,125 KW Hot Flue Gas@350 C & 381 KW Hot Flue Gas @320 C & $95.2 \%$ \\
\hline & 3,473 KW Electric Heater & 0 & $100 \%$ \\
\hline & 26,490 KW LP Steam@155 C & 25,691 KW LP Steam@160 C & $3.0 \%$ \\
\hline \multirow{2}{*}{ Area4 } & 246 KW HP Steam @ 255 C & 0 & $100 \%$ \\
\hline & 39,762 KW LP Steam@145 C & 23,675 KW LP Steam @160 C & $40.5 \%$ \\
\hline Area5 & 0 & 0 & - \\
\hline \multirow{4}{*}{$\begin{array}{c}\text { All } \\
\text { Networks } \\
(\mathbf{K W})\end{array}$} & 27,619 KW HP Steam @ 255 \& 260 C & 9,833 KW HP Steam@210 C & $64.4 \%$ \\
\hline & 132,779 KW LP Steam @ 145 \& 155 C & 92,501 KW LP Steam @ 160 \& 165 C & $30 \%$ \\
\hline & 7,551 KW Hot Flue Gas@ 290 \& 350 C & $\begin{array}{c}689 \text { KW Hot Flue Gas @ } 290 \text { \& } 320 \\
\text { C }\end{array}$ & $90.9 \%$ \\
\hline & 3,473 KW Electric Heater & 0 & $100 \%$ \\
\hline
\end{tabular}


Journal of Thermal Engineering, Research Article, Vol. 5, No. 4, pp. 341-354, July, 2019

\section{CONCLUSION}

As one of the conceptual methods in process integration, the pinch analysis is widely used as a suitable technique to evaluate and improve the energy systems. As a case study, the natural gas refinery of the South Pars Gas field in the Persian Gulf was chosen analyzed for energy requirement, in order to identify the type and temperature of appropriate utility as heating and cooling media in the total system.

The new network design improves total energy consumption about $35.52 \%$ relative to the existing one. Hot and cold utilities in the new network were 103,023 and 145,321 KW, respectively while the hot and cold utilities in the exiting network were 171,422 and 213,721 KW, respectively. Also, the results show that there was a considerable saving in both heating and cooling media. In this case study, there was about 38 and $100 \%$ reduction in cooling air and BFW respectively, but $45 \%$ increase in cooling water, as cold utilities, and almost $64.4,30.0,90.9$ and $100 \%$ reduction in HP steam, LP steam, hot flue gas and electric heater as hot utilities, respectively relative to the existing network.

In many cases, this method can be targeted for both energy and cost savings achieved at the same time, by selection of the best utilities as heating and cooling media. The result shows that in addition to the energy saving in the new network design, the distribution of utility media in heating and cooling processes were much better than the existing network.

\section{REFERENCES}

[1] Aramesh M., Kasaeian A., Pourfayaz F., Wen D. (2017). Energy analysis and shadow modeling of a rectangular type salt gradient solar pond. Solar Energy, 146, 161-171.

[2] Kasaeian A., Barghamadi H., Pourfayaz F. (2017). Performance comparison between the geometry models of multichannel absorbers in solar volumetric receivers. Renewable Energy, 105, 1-12.

[3] Aghaie M., Mehrpooya M., Pourfayaz F. (2016). Introducing an integrated chemical looping hydrogen production, inherent carbon capture and solid oxide fuel cell biomass fueled power plant process configuration. Energy Conversion and Management, 124, 141-154.

[4] Almutairi MF., Bourisli RI. (2017). Optimum Orientation of a Mutually-Shaded Group of Buildings with Respect to External Solar Radiation. Journal of Thermal Engineering, 3(1), 1065-1070.

[5] Ahmadi MH., Mehrpooya M., Pourfayaz F. (2016). Thermodynamic and exergy analysis and optimization of a transcritical $\mathrm{CO} 2$ power cycle driven by geothermal energy with liquefied natural gas as its heat sink. Applied Thermal Engineering, 109, 640-652.

[6] Khir T., Hafdhi F., Ben Yahia A., Ben Braim A. (2017). Exergetic Optimization of Phosphoric Acid Factory Power Plant. Journal of Thermal Engineering, 3 (5), 1428-1441.

[7] Ahmadi MH., Mehrpooya M., Pourfayaz F. (2016). Exergoeconomic analysis and Multi objective optimization of performance of a carbon dioxide power cycle driven by geothermal energy with liquefied natural gas as its heat sink. Energy Conversion Management, 119, 422-434.

[8] Kemp, Ian C. (2007). Pinch Analysis and Process Integration, A User Guide on Process Integration for the Efficient Use of Energy, Second ed., Elsevier Ltd., UK.

[9] Quijera, J.A.; García, A.; Alriols, M.G.; Labidi, “J. (2013). Heat integration options based on pinch and exergy analyses of a thermo solar and heat pump in a fish tinning industrial process. Energy, 55, 23-37.

[10] Mehdizadeh Fard, M., Pourfayaz, F., Kasaeian, A.B., Mehrpooya, M. (2017). A Practical Approach to Heat Exchanger Network Design in a Complex Natural Gas Refinery. Journal of Natural Gas Science and Engineering, 40C, 141-158.

[11] Khorrammanesh, M., Amidpoura, M., Nasr, M.R.J. (2007). Application of process decomposition in multistream plate fin heat exchangers design to use in heat recovery networks. Chemical Engineering and Processing, 46, 941-954.

[12] Tabatabaiyan, S., Rohani, A.A., Bahmanpour, H. (2014). Energy recycling in a gas refinery using a thermal exchanger system: The case of Masjed Soleiman gas refinery. European Journal of Experimental Biology, 4(3), 402 406.

[13] Kazempour, H., Pourfayaz, F., Mehrpooya, M. (2017). Modeling and multi-optimization of thermal section of Claus process based on kinetic model. Journal of Natural Gas Science and Engineering, 38, 235-244.

[14] Kianfar, E., Tayebinejad, E. (2014). Energy Optimization of Ilam Gas Refinery Unit 100 (stabilization) by using HYSYS REFINERY Software. International Research Journal of Applied and Basic Sciences, 8 (9), 1265-1270. 
[15] Joe, J.M., Rabiu, A.M. (2013). Retrofit of the Heat Recovery System of a Petroleum Refinery Using Pinch Analysis. Journal of Power and Energy Engineering, 1, 47-52.

[16] Keshavarzian, S., Verda, V., Colombo, E., Razmjoo, P. (2015). Fuel saving due to pinch analysis and heat recovery in a petrochemical company. Proceedings of ECOS 2015-The 28th International Conference on Efficiency, Cost, Optimization, Simulation and Environmental Impact of Energy Systems, Pau, France.

[17] Hamedni, N., Maddah, R. (2011). Description of Process and Utility Units of South Pars Gas Plants. University of Tehran Press, First Edition, Tehran.

[18] Kidnay, A.J., Parrish, W.R. (2006). Fundamentals of Natural Gas Processing, Taylor and Francis Group, CRC Press, NY.

[19] Hafeznia H., Pourfayaz F., Maleki A. (2017). An assessment of Iran's natural gas potential for transition toward low-carbon economy. Renewable and Sustainable Energy Reviews, 79, 71-81.

[20] Mehdizadeh Fard, M., Pourfayaz, F., Mehrpooya, M., Kasaeian, A.B. (2018). Improving energy efficiency in a complex natural gas refinery using combined pinch and advanced exergy analyses. Applied Thermal Engineering, 137, 341-355.

[21] Mehdizadeh Fard, M., Pourfayaz, F. (2018). A simple method for estimating the irreversibly in heat exchanger networks. Energy, 144, 633-646.

[22] Mehdizadeh Fard, M., Pourfayaz, F. (2019). Advanced exergy analysis of heat exchanger network in a complex natural gas refinery. Journal of Cleaner Production, 206, 670-687. 